Revue d'histoire de l'Amérique française

REVUE D.HISTOIRE DE L'AMÉRIQUE FRANÇAISE

\title{
Chronique de la Fondation Lionel-Groulx
}

\section{Juliette Rémillard}

Volume 27, numéro 1, juin 1973

URI : https://id.erudit.org/iderudit/303260ar

DOI : https://doi.org/10.7202/303260ar

Aller au sommaire du numéro

Éditeur(s)

Institut d'histoire de l'Amérique française

ISSN

0035-2357 (imprimé)

1492-1383 (numérique)

Découvrir la revue

Citer ce document

Rémillard, J. (1973). Chronique de la Fondation Lionel-Groulx. Revue d'histoire de l'Amérique française, 27(1), 150-150. https://doi.org/10.7202/303260ar d'utilisation que vous pouvez consulter en ligne.

https://apropos.erudit.org/fr/usagers/politique-dutilisation/ 


\section{CHRONIQUE DE LA FONDATION LIONEL-GROULX}

La Fondation Lionel-Groulx est heureuse de mettre à la disposition des chercheurs en histoire et autres disciplines, le fonds Michel-Brochu récemment déposé au siège même de la Fondation. Ce fonds comprend d'importants documents sur le Nouveau-Québec indien et esquimau et sur l'Arctique d'Amérique du Nord, travaux pour lesquels $M$. Brochu a consacré de longues années de recherche. Outre cette collection spécifique le fonds comprend, pour l'histoire du Québec, de nombreux dossiers sur l'indépendance, la question de la langue française, les Etats généraux, des collections de journaux rares, tels Pleins pouvoirs, Unir le Peuple, etc., des coupures de presse et de la correspondance.

La Fondation Lionel-Groulx a également reçu, du Juge Antonio Langlais, de Québec, une liasse de documents sur la famille Blanchet, en particulier sur l'évêque Augustin-Magloire (curé de Saint-Charles-sur-Richelieu, 1830-1838) ; l'archevêque François-Norbert; leur neveu, le prélat François-Xavier Blanchet, qui, tous trois, ont œuvré dans l'Orégon et $\mathrm{y}$ ont joué un rôle remarquable. Le troisième centenaire de naissance de Pierre Blanchet, l'ancêtre, a donné lieu à des fêtes grandioses, au Québec, en 1946.

Les généalogistes seront servis à souhait et les chercheurs en histoire trouveront leur profit à parcourir l'un ou l'autre de ces dossiers.

Il va sans dire que la Fondation Lionel-Groulx accueille avec plaisir et reconnaissance tout document que l'on veut bien lui confier. 